\title{
AUDIT ENERGI PROSES PENGOLAHAN TEH HITAM (CTC) DENGAN SISTEM PENGAMBILAN KEPUTUSAN METODE SPACE
}

\section{ENERGY ANALYSIS OF BLACK TEA PROCESSING PROCESS (CTC) WITH DECISION-MAKING SYSTEMS BY SPACE METHOD}

\author{
Muhammad Rizky Ramanda $^{1 凶}$, Sarifah Nurjanah ${ }^{2}$, Asri Widyasanti ${ }^{2}$ \\ ${ }^{1}$ Program Studi Teknologi Pangan, Institut Teknologi Sumatera \\ ${ }^{2}$ Program Studi Teknik Pertanian, Universitas Padjadjaran \\ 凶Komunikasi Penulis, email: muhammad.ramanda@tp.itera.ac.id \\ DOI:http://dx.doi.org/10.23960/jtep-lv10i2.183-192
}

Naskah ini diterima pada 8 Maret 2021; revisi pada 25 Maret 2021;

disetujui untuk dipublikasikan pada 6 April 2021

\begin{abstract}
The favorite product of black tea is tea leaf that are ground using the crush, tear and curl (CTC) method. This process able to produce the dry tea which has high quality with a strong aroma and taste, and high levels of antioxidants. This study aimed to conduct an energy analysis on the processing of black tea CTC at PTP. Nusantara VIII Rancabali to find out the steps towards efficient use of energy, opportunities and conservation efforts. The research method used is descriptive analysis method. The present paper conducted the energy audit calculations which are based on the energy consumption in each tea processing activity from the time. The calculation of energy audit was conducted from preparation of raw materials until the packaging of tea product. The results of the energy audit on the CTC black tea processing showed that for each ton of tea leaves required the energy is about 3,930.66 MJ.ton ${ }^{-1}$ The greatest energy use is drying process which is at 1,424.67 MJ.ton ${ }^{-1}$ or $36.24 \%$. The results of the analysis space was at quadrant conservative aggressive. Aggressive conservative steps that can be taken in the black tea processing are to develop activities towards energy saving, such as changing fuel from ordinary wood to wood pellets and adding or modifying machine tools so that the installed capacity of each processs to fulfill the capacity input of leaf tea.
\end{abstract}

Key words: CTC, energy analysis, energy saving, processing of tea

\begin{abstract}
ABSTRAK
Produk favorit dari teh hitam yaitu pucuk daun teh yang digiling dengan proses menggunakan metode crush, tear and curl (CTC), proses pembuatan teh kering ini mampu menghasilkan produk teh yang berkualitas tinggi dengan aroma dan rasa yang kuat, air seduhan yang pekat serta memiliki tingkat antioksidan yang tinggi. Tujuan penelitian adalah melakukan audit energi pada proses pengolahan teh hitam CTC di PTP. Nusantara VIII Rancabali sehingga dapat diketahui langkah menuju efisiensi penggunaan energi, peluang dan usaha konservasi. Metode penelitian yang digunakan yaitu metode analisis deskriptif. Perhitungan audit energi dilaksanakan berdasarkan pemakaian energi pada setiap kegiatan proses pengolahan teh mulai saat proses pengangkutan bahan baku sampai pengepakan. Hasil penelitian proses teh hitam CTC untuk satu ton daun pucuk teh membutuhkan energi sebesar 3.930,66 MJ/ton. Pemakaian energi terbesar terjadi pada proses pengeringan yang mencapai 1.424,67 $\mathrm{MJ} /$ ton atau 36,24\%. Hasil analisis SPACE berada pada kuadran konservatif agresif. Langkah konservatif agresif yang bisa dilakukan pada proses pengolahan teh hitam yaitu dengan melakukan pengembangan kegiatan menuju arah penghematan energi seperti pergantian bahan bakar dari kayu biasa menjadi wood pellet dan penambahan atau memodifikasi alat mesin sehingga kapasitas yang terpasang setiap proses dapat memenuhi input pucuk yang datang.
\end{abstract}

Kata Kunci : audit energi, CTC, pengolahan teh, penghematan energi 


\section{PENDAHULUAN}

Energi yaitu suatu yang tidak dapat dimusnahkan dan diciptakan, namun energi dapat dikonversi dari satu dimensi ke dimensi yang lainnya (Moran et al., 2006). Energi juga dapat dipahami sebagai kemampuan atau usaha dalam memberikan akibat atau pengaruh yang ditimbulkan, baik seperti proses panas yang dilakukan oleh suatu usaha atau proses mekanik. (Laksmana, 2007).

Penggunaan kayu bakar atau kayu biasa sebagai pengganti alternatif energi fosil dalam proses pengolahan produksi hasil pertanian merupakan salah satu solusi yang nyata dalam peningkatan produksi pertanian (Hatirli et al., 2006). Salah satu produksi hasil pertanian adalah teh hitam. Dengan semakin tinggi kebutuhan kayu bakar untuk memproduksi hasil pertanian maka semakin meningkat pula harganya. Pembakaran menggunakan kayu bakar juga dapat merugikan menimbulkan masalah kesehatan makhluk hidup yang ada disekitarnya seperti asma, batuk, mata perih dan mampu menyebabkan kanker jika terpapar terlalu lama (Herwanto et al., 2018).

Teh (Camellia sinensis L.) di Indonesia merupakan tanaman yang digunakan secara turun menurun sebagai minuman. Teh dikelompokkan menjadi tiga jenis berdasarkan proses pengolahannya yaitu teh hitam, teh olong atau hijau dan teh putih. Yang membedakan dari beberapa jenis tersebut yaitu adanya perlakuan oksidasi enzimatis. Oksidasi enzimatis bertujuan untuk mengubah polifenol menjadi senyawa yang membentuk karakteristik warna teh hitam kemudian menghasilkan senyawa tehaflavin dan teharubigin yang menentukan sifat air seduhan teh (quality, strength, briskness dan colour) (Jain, 2007).

Teh hitam dibuat dari daun atau pucuk teh, Jenis tanaman yang sama digunakan dalam pembuatan produk olahan teh hijau (Suprihatini, 2005). Tetapi, daun atau pucuk teh tersebut digiling, difermentasi dan dikeringkan, sehingga warna bubuk teh menjadi coklat kehitaman dan memiliki macam rasa yang beragam. Tidak seperti banyak varietas lainnya, teh hitam memiliki kandungan antioksidan yang tinggi dan memiliki kandungan polifenol yang bermanfaat dalam mendukung fungsi kekebalan yang sehat, menumbuhkan imun dan memerangi peradangan pada tubuh. Teh hitam juga memiliki kandungan asam amino dan kafein sehingga bermanfaat untuk mempertajam konsentrasi, meningkatkan energi dan melancarkan peredaran tubuh. (Indarti, 2015). PT. Perkebunan Nusantara VIII adalah perusahaan Indonesia yang mengelola dan memproduksi teh kering yang ada di Jawa Barat.

Proses pengolahan teh hitam di Indonesia terbagi menjadi dua yaitu jenis proses tradisional dan jenis proses CTC (Crush, Tear, Curl). Sistem tahapan pengolahan secara tradisional dan CTC hampir sama, dengan tahapan terdiri dari pengambilan pucuk segar, pelayuan, penggulungan atau penggilingan, oksidasi enzimatis, pengeringan, sortasi kering, dan pengepakan (Setyamidjaja, 2000). Berbeda dengan pengolahan teh tradisional, pengolahan CTC merupakan proses penggilingan yang membutuhkan tingkat kelayuan yang tidak terlalu kering (saat kadar air pada teh mencapai $68 \%$ hingga $73 \%$ ) dengan sifat penggilingan dan pencacahan yang cukup padat. Sebaliknya, proses pengolahan tradisional memerlukan tingkat kelayuan yang cukup kering (kandungan air $55 \%$ sampai $60 \%$ ) dengan sifat penggilingan dan pembentukan yang lebih besar (Herwanto et al., 2018). Potongan yang keriting dan berbentuk butiran pipih serta berwarna lebih hijau setelah proses penggilingan merupakan ciri-ciri fisik teh dari proses pengolahan CTC. Rasa yang lebih kuat (strong), warna air dari seduhan teh yang lebih pekat dan waktu larut yang lebih cepat merupakan sifat-sifat yang terdapat di dalam teh hitam pengolahan CTC. (Setiawati dan Nasikun, 1991). Bahan baku pada pucuk atau daun teh yang dipilih dan metode pengolahannya sangat berpengaruh pada kualitas akhir teh hitam (Sutejo, 2018).

Analisis terhadap kebutuhan energi pada pengolahan teh metode CTC pada PTPN VIII Kebun Rancabali diperlukan karena beberapa mesin yang ada di pabrik CTC sudah cukup lama beroperasi tanpa perawatan yang rutin sehingga proses pengolahan teh hitam kurang efektif. Hasil dari audit energi ini bisa dijadikan sebagai referensi bagi PTPN ataupun perusahaan lain agar mampu meningkatkan efisiensi dengan lebih 
baik sehingga dapat mencari alternatif penghematan energi dan dapat menekan biaya produksi sehingga kemudian akan berfokus untuk meningkatkan kualitas dan daya saing teh hitam yang dihasilkan.

Tujuan penelitian adalah melakukan audit energi di PTPN VIII Kebun Rancabali pada proses pengolahan teh hitam CTC sehingga dapat diketahui langkah menuju efisiensi penggunaan energi, peluang dan usaha konservasi. Penelitian ini juga dilakukan untuk menentukan strategi penghematan energi di PTPN VIII Kebun Rancabali khususnya proses pengolahan teh hitam CTC.

\section{BAHAN DAN METODE}

Penelitian ini dilaksanakan di Pabrik Teh PTPN VIII Kebun Rancabali, Kecamatan Patenggang, Provinsi Jawa Barat. Alat yang digunakan yaitu, buku survey (buku tulis), Stopwatch, clampmeter, pita ukur, laptop, timbangan, smartphone, software Microsoft excel 2010. Bahan yang dipakai adalah data pokok dan data tambahan. Data pokok diambil dari pengamatan dan penelitian secara langsung dengan proses pengukuran dan perhitungan, serta wawancara. Sedangkan data tambahan yang dipakai adalah data kebutuhan energi secara tak langsung disetiap mesin pada proses pengolahan teh hitam CTC, waktu yang diperlukan dalam setiap tahapan, jenis alat dan mesin berserta jumlahnya, total tenaga pekerja, dan semua sarana produksi yang dipakai ataupun yang berasal dari literatur.

\subsection{Tahapan Penelitian}

Penelitian ini dilakukan dengan beberapa tahapan. Tahapan tersebut dapat dilihat pada Gambar 1.

\subsubsection{Pengumpulan Data}

Pengumpulan data dilaksanakan untuk mengamati jadwal kegiatan kerja, waktu yg digunakan saat berkegiatan setiap proses, total tenaga pekerja, jumlah dan jenis alat mesin, energi pada setiap proses pengolahan seperti energi manusia, energi langsung (listrik dan bahan bakar) serta energi tak langsung, dan identifikasi bentuk energi beserta jumlahnya.

\subsubsection{Pengolahan Data}

Menurut Abdalla et al. (2017), pemakaian energi pada proses pengolahan teh hitam CTC berdasarkan persamaan berikut:

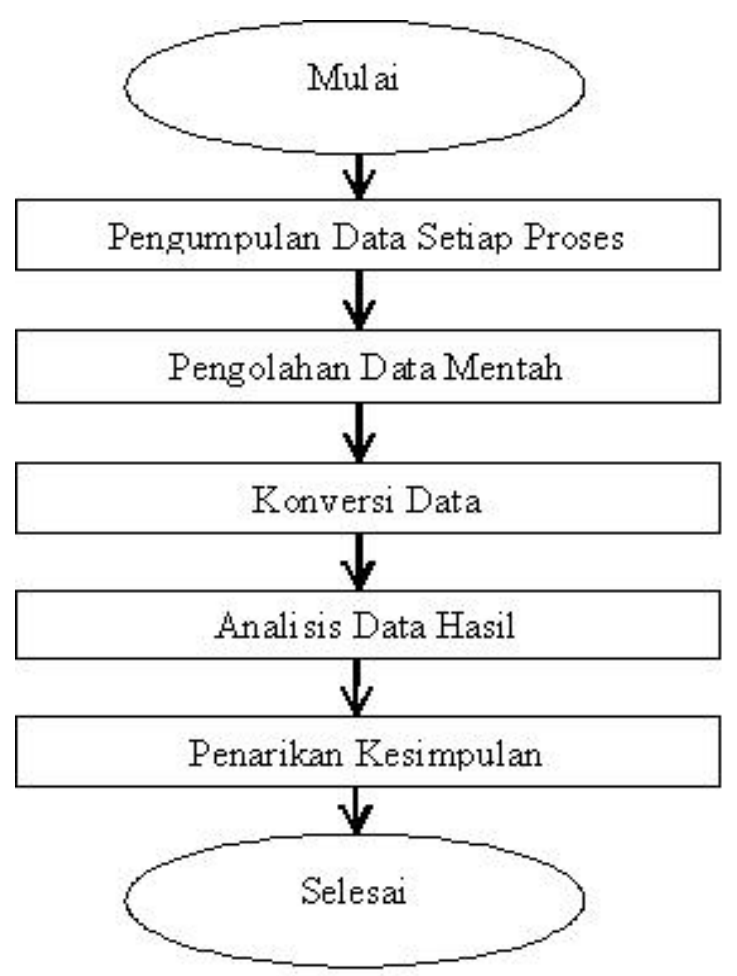

Gambar 1. Tahapan Penelitian 


\section{a. Energi Manusia}

$$
\mathrm{Ebp}=\mathrm{HK}^{*} \mathrm{~J}^{*} \mathrm{cb}^{*} \mathrm{Rd}
$$

Dimana, Ebp adalah energi manusia (MJ/t), HK adalah jumlah hari orang kerja per ton (hari/t), J adalah jam kerja per hari (jam/hari), Rd adalah rendemen (\%), dan cb adalah nilai energi biologis (MJ/jam).

\section{b. Energi Langsung}

$$
\mathrm{ELP}=\left(\mathrm{KL}^{*} \mathrm{CL} * \mathrm{Rd}\right) / \mathrm{CH}
$$

Dimana, ELP adalah energi langsung proses pengolahan menggunakan bahan bakar $(\mathrm{MJ} / \mathrm{t})$, KL adalah konsumsi kayu atau wood pellet $(\mathrm{kg} /$ jam), $\mathrm{Cl}$ adalah nilai unit energi kayu atau wood pellet $(\mathrm{MJ} / \mathrm{kg})$, dan $\mathrm{CH}$ adalah kapasitas lapangan efektif alsin (t/jam).

\section{c. Energi Tidak Langsung}

$$
\mathrm{Ee}=\frac{((m x c e b)+(m x c e k)) \cdot((0,82+(0,33 * T A R))}{N x P}
$$

Dimana, m adalah massa alat dan mesin pertanian $(\mathrm{kg})$, ceb adalah nilai energi tak langsung proses $(\mathrm{MJ} / \mathrm{kg})$, cek adalah nilai energi tak langsung alat mesin (MJ/kg), TAR adalah koefisien perbaikan (\%) yaitu perbandingan biaya perbaikan dan perawatan akumulasi harga sebenarnya pada umur alat, $\mathrm{N}$ adalah umur ekonomis alat dan mesin pertanian (jam), dan $\mathrm{P}$ adalah kapasitas alat dan mesin pertanian $(\mathrm{t} /$ jam).

\section{d. Energi Listrik}

$$
\mathrm{EL}=\mathrm{KL} * \mathrm{NEL}
$$

Dimana, EL adalah energi listrik proses pengolahan $(\mathrm{MJ} / \mathrm{t}), \mathrm{KL}$ adalah konsumsi listrik proses pengolahan $(\mathrm{kWh} / \mathrm{t})$, dan NEL adalah nilai energi listrik per kWh (MJ/kWh).

\subsubsection{Konversi Data.}

Konversi data yaitu melakukan persamaan satuan dari hasil pengolahan data setiap proses pengolahan sehingga menjadi satuan MJ/ton.

\subsubsection{Analisis Data.}

Hasil dari pengkonversian data dan perhitungan total nilai dari wawancara dianalisis agar dapat menentukan tahapan dalam penghematan energi menggunakan metode SPACE.

\subsection{Analisis SPACE}

Analisis SPACE merupakan salah satu metode pengambilan keputusan dengan membandingkan antara faktor internal yaitu keunggulan kompetitif dan kekuatan finansial dengan faktor eksternal yaitu kestabilan lingkungan dan kekuatan industri. Nilai dari kekuatan finansial (FS) dan kestabilan lingkungan (ES) akan diperoleh nilai pada sumbu $y$, sementara keunggulan kompetitif (CA) dan kekuatan industri (IS) dimasukkan ke dalam sumbu x (David, 2011).

\section{HASIL DAN PEMBAHASAN}

\subsection{Rendemen Proses Pengolahan Teh Hitam CTC}

Pengolahan adalah proses terjadinya suatu bahan baku atau bahan mentah menjadi produk yang dinginkan. Dalam proses pengolahan khususnya teh terdapat perbedaan rendemen dari sebelum diolah dengan setelah proses pengolahan, perhitungan rendemen diketahui dengan perbedaan massa/berat teh kering yang dihasilkan dari proses pengolahan (teh hitam setelah proses pengepakan) dengan massa atau berat bahan baku (pucuk segar hasil panen) sebelum memasuki proses.

Rendemen total setiap proses pengolahan teh hitam CTC yaitu 22,8\% dimana sebelum teh diolah memasuki proses pelayuan, massa atau berat teh pucuk segar adalah 20,36 ton. Setelah mengalami berbagai proses perlakuan, teh hitam kering menghasilkan massa/berat sebanyak 4,64 ton. Perhitungan rendemen tiap proses dimulai dari membandingkan massa teh hitam setelahmelalui proses pengolahan ( product) dengan massa teh segar sebelum proses pengolahan (raw material). Proses pelayuan adalah tahapan yang rendemen paling banyak, yaitu sebesar $77,79 \%$ dan proses pengeringan memiliki rendemen terbesar kedua yaitu 30,40\%. Hal ini terjadi karena ada proses penurunan kadar air teh pada proses pelayuan dan pengeringan. Proses pelayuan dilakukan memakan waktu berkisar 12-13 jam dan proses pengeringan dilakukan memakan waktu berkisar 20-22 jam. Pada tahapan pelayuan ini juga dilakukan penurunan kadar air untuk mempermudah tahapan proses penggilingan 
pucuk teh sedangkan pada tahapan pengeringan penurunan kadar air dilakukan untuk membentuk dan menghasilkan biji teh kering. Beda dengan ortodoks, pengolahan dengan CTC memiliki tingkat kadar air yang lebih tinggi karena dibutuhkan sebagai pelumas alami agar pada saat proses penggilingan daun teh lebih mudah untuk dicacah dan digiling serta agar membuat mesin tidak terlalu panas. Rendemen tiap tahapan proses ada pada Tabel 1 .

\subsection{Analisis Energi Pengolahan Teh Hitam CTC}

Perhitungan penggunaan energi pada proses pengolahan teh hitam CTC di PTP. Nusantara VIII Rancabali dimulai dari kegiatan setelah panen di kebun. Kegiatan atau proses yang dilakukan meliputi proses pengangkutan bahan baku pucuk segar atau hasil panen dari tiap bagian kebun, pelayuan, penggilingan, fermentasi/ oksidasi enzimatis, pengeringan, soratsi kering, dan pengepakan. Setiap proses pengolahan tersebut mempunyai energi input dimana energi yang masuk berasal dari energi langsung dan tak langsung, kemudian energi tersebut dianalisis dan dikonversi menjadi satuan energi per ton.

Energi langsung yang diolah untuk menjadi perhitungan audit energi meliputi penggunaan energi yang berasal energi bahan bakar dan energi listrik, kemudian energi yang dihitung dalam bagian tenaga kerja yaitu dari energi manusia atau energi biologis beserta jumlah pekerja pada setiap prosesnya, sedangkan energi tak langsung (embodied energy) dari kandungan bahan yang dipakai dalam tahapan pengolahan teh serta alat dan mesin proses pengolahan dan bahan yang digunakan selama proses pengolahan teh.
Berdasarkan analisis dan perhitungan data tahapan proses sortasi kering memiliki nilai konsumsi energi listrik terbesar yaitu 505,73 $\mathrm{MJ} /$ ton. Hal ini dikarenakan penggunaan waktu pengolahan tanpa henti yang cukup lama membuat mesin sortasi kering harus bekerja lebih ekstra sehingga konsumsi daya listrik menjadi meningkat, serta perawatan rutin terhadap alat dan mesin yang terlibat pada proses ini merupakan cara yang tepat agar penggunaan energi tetap selaras dengan kinerja alat dan mesin. Total energi input pada proses pengolahan teh hitam CTC yang dilakukan di PTP Nusantara VIII Rancabali adalah sebesar 3.930,66 MJ/ton pucuk teh dengan average yields 20 ton/hari. Secara keseluruhan masukan energi proses pengolahan teh hitam CTC disajikan pada Tabel 2 .

Pada Gambar 2 dapat dilihat persentase penggunaan energi keseluruhan proses pengolahan teh hitam CTC. Tahapan proses pengeringan merupakan penggunaan energi terbanyak secara keseluruhan dengan nilai sebesar 1.424,67 MJ/ton pucuk teh atau 36,25\% dari seluruh energi input pada proses pembuatan teh hitam CTC. Tahapan proses pengeringan menjadi proses dengan penggunaan terbesar dikarenakan besarnya energi yang masuk, terutama pada bahan bakar padat yang digunakan bahan bakar kayu kering dan wood pellet dengan perbandingan $1: 1$. Nilai energi langsung (bahan bakar) tersebut yaitu 1.363,15 $\mathrm{MJ} /$ ton. Proses pengeringan ini membutuhkan waktu berkisar 22 jam dan suhu yang dipakai untuk menguapkan air pada teh hitam tersebut mencapai $55^{\circ} \mathrm{C}$. Kadar air yang harus tercapai dalam standar teh hitam kering yaitu $\pm 2,5 \%$ dimana kadar air teh awal setelah proses fermentasi yaitu $\pm 70 \%$, oleh karena itu dalam proses pengeringan ini membutuhkan waktu

Tabel 1. Rendemen Tiap Proses Pengolahan Teh CTC

\begin{tabular}{lccc}
\hline \multicolumn{1}{c}{ Proses } & Input (ton) & Output (ton) & Rendemen (\%) \\
\hline Pengangkutan & 20,36 & 20,36 & $100 \%$ \\
Pelayuan & 20,36 & 15,84 & $77,79 \%$ \\
Penggilingan & 15,84 & 15,80 & $99,74 \%$ \\
Fermentasi & 15,80 & 15,79 & $99,95 \%$ \\
Pengeringan & 15,79 & 4,80 & $30,40 \%$ \\
Sortasi Kering & 4,80 & 4,64 & $96,66 \%$ \\
Pengepakan & 4,64 & 4,64 & $100 \%$ \\
\hline \multicolumn{1}{c}{ Total } & & $\mathbf{2 2 , 8 0 \%}$ \\
\hline
\end{tabular}


yang cukup lama agar mampu menguapkan air mencapai 52,5\%. Presentase energi total pengolahan teh hitam CTC ditampilkan pada Gambar 2.

\subsection{Analisis SPACE}

Matriks SPACE (Strategix Position and Action Evaluation) digunakan untuk sebagai pengambilan keputusan dalam menentukan strategi perusahaan dengan melihat aspek eksternal dan internalnya. Nilai yang dipakai ada dua faktor internal yakni competitive advantage (CA) dan financial strength (FS), serta dua faktor eksternal yaitu industrial strength (IS) dan environment stability (ES). Matriks SPACE merupakan penyempurnaan dari metode IFE/ EFE dan metode SWOT. Analisis SPACE membandingkan antara faktor eksternal stabilitas lingkungan dan kekuatan industri dengan faktor internal kekuatan finansial dan keunggulan kompetitif. Posisi kekuatan finansial (FS) dan stabilitas lingkungan (ES) sehingga diperoleh nilai titik pada sumbu y, sementara keunggulan kompetitif (CA) dan kekuatan industri (IS) dimasukkan ke dalam sumbu $\mathrm{x}$ (David, 2011).

Nilai kuisioner dari matriks SPACE memiliki bobot penilaian satu sampai lima dengan pertanyaan yang mengarah ke faktor strategi internal dan eksternal. Hasil dari penilaian tersebut selanjutnya dikonversikan menggunakan perhitungan matriks SPACE. Ada 3 tahapan perhitungan yang harus dilakukan, yaitu:

1)Proses perhitungan bobot dan skor poin pada setiap faktor FS-ES-CA-IS.

2)Proses pengurangan antara jumlah total faktor FS dengan ES dan faktor CA dengan IS, dimana perolehan angka tersebut menjadi nilai atau titik $\mathrm{y}$ dan $\mathrm{x}$.

3)Penentuan posisi kuadran yang ditentukan oleh titik Y dan X pada matriks SPACE.

Matriks SPACE digunakan pada penelitian kali ini untuk mengetahui langkah yang paling

Tabel 2. Total Energi Input Proses Pengolahan Teh Hitam CTC

\begin{tabular}{lcccc}
\hline \multicolumn{1}{c}{ Proses } & $\begin{array}{c}\text { Energi Langsung } \\
\text { dan Manusia } \\
\text { (MJ/ton) }\end{array}$ & $\begin{array}{c}\text { Energi Tak } \\
\text { Langsung } \\
\text { (MJ/ton) }\end{array}$ & $\begin{array}{c}\text { Total Energi } \\
\text { (MJ/ton) }\end{array}$ & \% \\
\hline Pengangkutan bahan & 116,52 & 137,29 & 253,82 & 6,46 \\
baku & 335,46 & 179,06 & 514,52 & 13,09 \\
Pelayuan & 440,60 & 269,38 & 709,99 & 18,06 \\
Penggilingan & 31,04 & 21,49 & 52,54 & 1,34 \\
Fermentasi & 1363,15 & 61,52 & 1424,67 & 36,25 \\
Pengeringan & 520,14 & 339,27 & 859,41 & 21,86 \\
Sortasi Kering & 78,17 & 37,51 & 115,69 & 2,94 \\
Pengepakan & $\mathbf{2 8 8 5 , 1 1}$ & $\mathbf{1 0 4 5 , 5 5}$ & $\mathbf{3 9 3 0 , 6 6}$ & $\mathbf{1 0 0 , 0 0}$ \\
\hline \multicolumn{1}{c}{ Total } & & & & \\
\hline \multicolumn{1}{c}{}
\end{tabular}

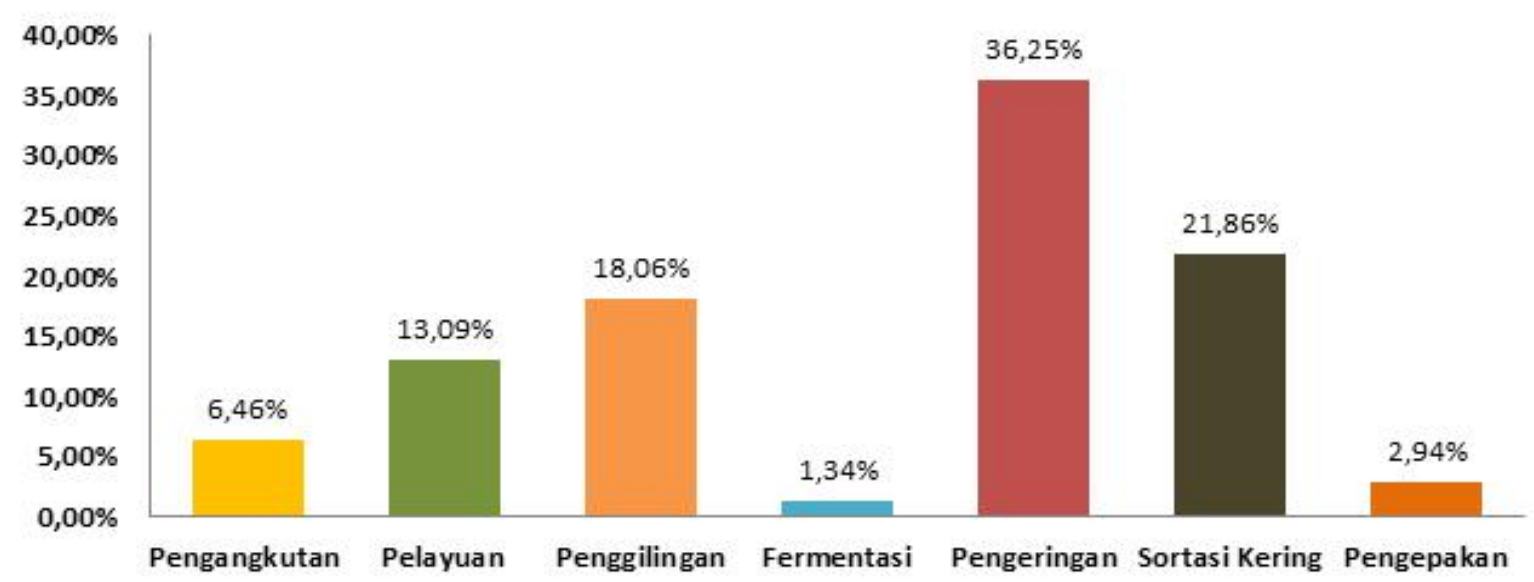

Gambar 2. Persentase Energi Proses Pengolahan Teh Hitam CTC 
optimal untuk melakukan konservasi serta penghematan energi pada proses pengolahan teh hitam CTC. Matriks SPACE dilakukan dengan cara mewawancarai lima orang diantara lain, Manager Kebun, Kepala Pengolahan, Mandor Besar Basah, Mandor Besar Kering, Mandor Besar Quality Control. Beberapa pertanyaan SPACE berfokus kepada bahan bakar wood pellet karena wood pellet merupakan bahan bakar alternatif pengganti kayu bakar maka perlu analisis lebih lanjut terhadap penghematan energi pabrik CTC.

Data kualitatif pada analisis SPACE dari wawancara kemudian diubah menjadi data kuantitatif agar dapat diketahui secara terukur kondisi pabrik pengolahan teh hitam CTC sehingga dapat dilakukan analisis perencanaan strategis yang digunakan untuk mengevaluasi proses pengolahannya. Nilai pada hasil perhitungan setiap faktor SPACE kemudian disajikan dalam bentuk kuadran untuk mengetahui langkah yang digunakan untuk penghematan energi khususnya pada proses pengolahan teh hitam CTC. Hasil perhitungan analisis SPACE dapat terlihat pada Gambar 3.

1. Sumbu Y matriks SPACE

$$
\mathrm{FS}+\mathrm{ES}=21+(-20)=1
$$

2. Sumbu X matriks SPACE

$$
\mathrm{IS}+\mathrm{CA}=24+(-24)=0
$$

Penentuan kuadran pada matriks SPACE dipenelitian pengolahan teh hitam CTC menghasilkan koordinat titik 0 pada sumbu $\mathrm{x}$ dan 1 pada sumbu y sehingga langkah yang seharusnya dilakukan menuju efisiensi energi adalah dengan melakukan langkah konservatif agresif. Nilai hasil analisis SPACE ini berada pada tengah-tengah kuadran I dan IV dimana pada kuadran ini menyatakan bahwa nilai langkah penghematan energi adalah dengan melakukan langkah agresif serta mempertimbangkan langkah konservatif.

Penghematan energi PTPN VIII Pabrik CTC Kebun Rancabali berada pada kuadran konservatif agresif dimana kuadran tersebut mengindikasikan bahwa pabrik CTC berada posisi terbaik dimana dalam usaha penghematan energi tercapai dengan menggunakan bahan bakar alternatif yaitu wood pellet. Berdasarkan hasil wawancara dengan kepala pengadaan Kebun Rancabali, pengeluaran bahan bakar kayu pada pabrik CTC yaitu sebesar 11 per meter kubik dimana satu meter kubik sama dengan $\pm 400 \mathrm{~kg}$. harga satu meter kubik kayu untuk 6 bulan terakhir sekitar \pm Rp. 385.000 atau sekitar Rp. 962,5 per kg. Hal ini membuat perusahaan harus mengeluarkan biaya sekitar $\pm \mathrm{Rp}$. 4.235.000 per satu kali proses, sedangkan dengan wood pellet cukup dengan $\pm \mathrm{Rp} 3.888 .000$ dalam satu kali proses dengan harga dalam triwulan terakhir \pm Rp. 1.220 per kg. Perhitungan biaya kebutuhan kayu biasa dan wood pellet bisa dilihat pada Tabel 3 .

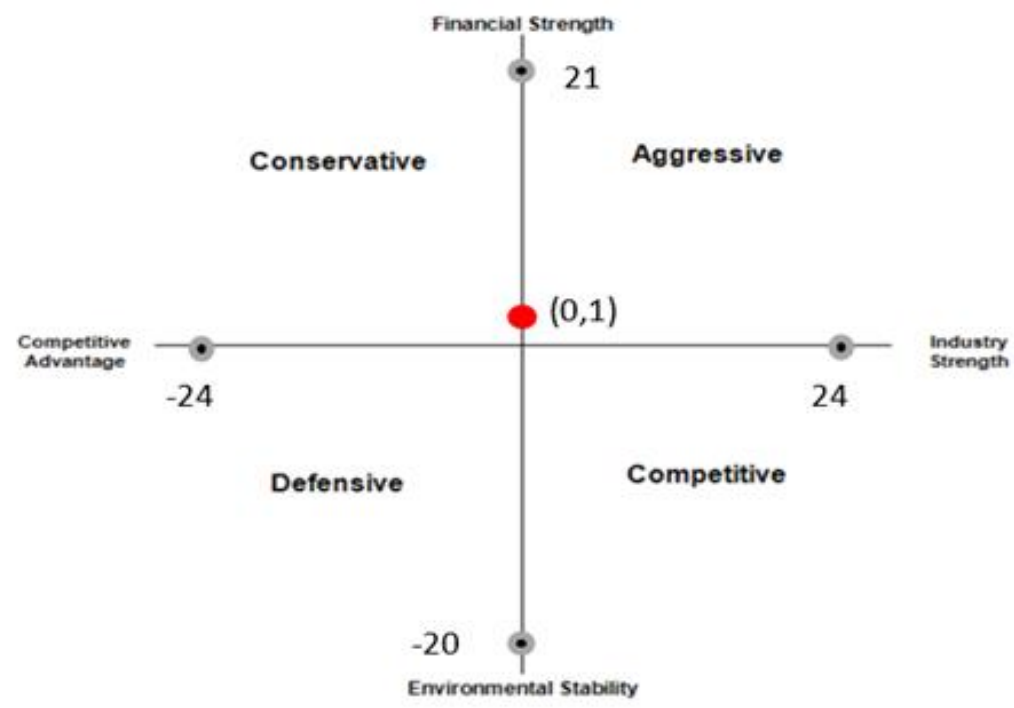

Gambar 3. Hasil Kuadran Matriks SPACE 
Tabel 3. Biaya Kebutuhan Bahan Bakar (Kayu Biasa dan Wood Pellet) Proses Pengeringan

\begin{tabular}{lccc}
\hline Bahan Bakar & $\begin{array}{c}\text { Kebutuhan Bahan } \\
\text { Bakar (Kg) }\end{array}$ & Harga satuan kg (Rp) & Biaya Total (Rp) \\
\hline Kayu & 4400 & 962,5 & 4.235 .000 \\
Wood Pellet & 3187 & 1220 & 3.888 .140 \\
\hline
\end{tabular}

Suhu panas pada heat exchanger dengan menggunakan wood pellet lebih konstan dibanding kayu karena dalam proses pembakaran menggunakan bahan bakar wood pellet dibantu dengan mesin burner. Suhu pada inlet heat exchanger tersebut sekitar 110 - 120 ${ }^{\circ} \mathrm{C}$.

Strategi lanjutan sesuai dengan kuadran agresif konservatif dalam penghematan energi yang dibutuhkan oleh pabrik CTC yaitu dengan strategi ekspansi (growth). Menurut Yuliani, 2019, langkah strategi didalam kuadran agresif yaitu dengan strategi ekspansi (growth). Berdasarkan pengambilan data actual mesin pada Pabrik CTC tidak mampu memenuhi input pucuk teh yang datang sehingga waktu yang dibutuhkan dalam satu kali proses memakan waktu yang cukup lama sekitar 20 - 22 jam sehingga strategi ekspansi ini perlu dilakukan dengan penambahan alat dan mesin, atau memodifikasi mesin Green Leaf Shifter, Rotorvane, mesin CTC serta conveyor agar kapasitas yang terpasang setiap proses dapat memenuhi input pucuk yang datang.

\subsection{Peluang Perawatan Mesin}

Usaha dalam penghematan energi bisa diterapkan bersamaan dengan peluang dalam perawatan mesin untuk berkelanjutan. Usaha tersebut dapat dikategorikan dengan penghematan secara teknis dan non teknis (Sugandi et al., 2017). Secara teknis yaitu: penambahan alat dan mesin atau modifikasi mesin sehingga kapasitas bertambah, pengecekan, perbaikan dan pemeliharaan alat dan mesin secara teratur baik sebelum dan sesudah digunakan, penggunaan peralatan dan mesin secara efektif sesuai standar prosedur yang ada, penggantian peralatan yang bekerja di luar karakteristik kerja dan umur kerja (peremajaan) serta perbaikan pada prasarana penunjang proses pengolahan seperti jalan dari kebun menuju pabrik pengolahan dan bangunan pabrik pengolahan. Penghematan secara non teknis yaitu: workshop atau pelatihan atau penyuluhan kepada para pekerja pabrik atau lapangan agar memahami operasi penggunaan alat dan mesin pada setiap tahapan proses pengolahannya sesuai SOP yang berlaku serta memberikan pemahaman tentang pentingnya proses penghematan energi.

\subsection{Peluang Penghematan Energi Bahan Bakar Padat Pada Proses Pengeringan}

Kebutuhan energi total baik energi langsung dan tak langsung pada proses pengeringan adalah $36,24 \%$ dari keseluruhan energi input dengan efisiensi sebesar $20,15 \%$. Nilai total energi ini mampu dikategorikan sebagai kategori efisien karena dari perhitungan efisiensi energi pengeringan masih memiliki nilai energi tersisa atau surplus. Dari total nilai penggunaan energi, bahan bakar kayu mencapai 82,91\% dan energi listrik mencapat $17,08 \%$ dimana energi listrik yang digunakan oleh mesin dan conveyor. mesin VFBD (Vibro Fluid Bed Dryer) merupakan mesin yang digunakan untuk proses pengeringan di PTP. Nusantara VIII Kebun Rancabali dengan suhu inlet dimesin tersebut berkisar $90-110^{\circ} \mathrm{C}$ dan suhu outlet mencapai $48-55^{\circ} \mathrm{C}$. Pada proses penggunaannya, bahan bakar (kayu) harus selalu dipantau atau diamati dimana kayu harus dimasukkan kedalam heat exchanger sebelum pembakaran dengan wood pellet. Hal ini disebabkan karena arang kayu bakar membuat suhu heat exchanger panas lebih lama.

Wood pellet sangat dibutuhkan dalam proses pembakaran ini karena panas/kalor yang dihasilkan mampu membantu proses pengeringan daun teh yang sudah melewati proses penggilingan dan fermentasi sehingga daun teh tersebut akan membentuk butiranbutiran atau granula teh kering yang dimana teh kering tersebut akan disortasi kemudian siap dikemas. Tahapan proses pembakaran menggunakan mesin Heat Exchanger (HE) yaitu kayu bakar atau wood pellet dimasukkan kedalam tungku kemudian kalor tersebut masuk 
Tabel 4. Perhitungan Biaya Energi Langsung Listrik Pengolahan Teh CTC

\begin{tabular}{cccc}
\hline Mesin & $\begin{array}{c}\text { Daya Listrik } \\
\text { (kWh) }\end{array}$ & $\begin{array}{c}\text { Harga Listrik } \\
\text { (Rp/kWh) }\end{array}$ & $\begin{array}{c}\text { Jumlah Biaya (Rp/ } \\
\text { Tahun) }\end{array}$ \\
\hline $\begin{array}{c}\text { Kapasitas 1000-1200 } \\
\text { kg/jam }\end{array}$ & 3657,76 & 996,74 & 1.137 .489 .33 \\
\hline
\end{tabular}

Tabel 5. Perhitungan Biaya Energi Langsung Listrik (Setelah Modifikasi)

\begin{tabular}{cccc}
\hline Mesin & $\begin{array}{c}\text { Daya Listrik } \\
\text { (kWh) }\end{array}$ & $\begin{array}{c}\text { Harga Listrik } \\
\text { (Rp/kWh) }\end{array}$ & $\begin{array}{c}\text { Jumlah Biaya (Rp/ } \\
\text { Tahun) }\end{array}$ \\
\hline $\begin{array}{c}\text { Kapasitas 1500-1700 } \\
\text { kg/jam }\end{array}$ & 2453,9 & 996,74 & $763.121,01$ \\
\hline
\end{tabular}

kedalam pipa-pipa udara/cerobong dimana setelah itu ada kipas utama yang menghisap udara panas tersebut menuju ruangan pengeringan atau drier box.

Tingkat kekeringan atau tingkat kadar air wood pellet sangat berpengaruh pada saat proses pembakaran di mesin pengering tersebut. Wood pellet dengan kadar air tinggi atau lebih dari $10 \%$ bisa membuat tungku pembakaran (burner), pipa-pipa udara/cerobong (heat exchanger), dan kipas utama untuk mengalirkan udara panas ke ruang pengeringan (main fan) menjadi berkarat atau korosi. Oleh karena itu perlu adanya penyimpanan dan pemeliharaan wood pellet tersebut diruangan yang memiliki nilai $\mathrm{RH}$ yang rendah agar selalu dalam keadaan kering.

Penghematan energi yang bisa dilakukan pada tahap proses pengeringan yaitu dengan melakukan perawatan secara rutin sebelum dan setelah proses produksi dimana proses pembersihan tersebut dengan cara mengeluarkan ampas atau sisa-sisa dari debu bahan bakar tersebut sehingga pada proses produksi selanjutnya mesin tetap dalam kondisi prima dan menghasilkan udara panas yang optimal serta perlu ada proses controlling disetiap pipa-pipa mesin tersebut agar tidak terjadi kebocoran sehingga ampas/debu dari bahan bakar tidak ikut masuk dalam ruangan pengeringan (drier box). Ketika proses pembakaran memasuki kondisi optimal maka proses pengeringan bisa dilakukan lebih cepat dari waktu biasanya, sehingga bisa menghemat waktu serta menghemat biaya proses produksi pada tahapan selanjutnya.

\subsection{Peluang Penghematan pada Sistem Pasokan Listrik}

Dari sisi ekonomi, menggunakan listrik dari PLN secara keseluruhan, biaya pertahunnya menjadi sekitar Rp. 1.137 M jika konsumsi rata-rata penggunaan listrik untuk pengolahan setiap hari adalah 3657,76 kWh (berdasarkan perhitungan energi penggunaan listrik) dengan tarif dasar listrik Rp. 996,74/kWh. Perhitungan ekonomi daya listrik ada pada Tabel 4.

Jumlah pucuk teh yang datang sebesar 20,36 ton dengan kapasitas mesin penggiling rata-rata $1000-1200 \mathrm{~kg} / \mathrm{jam}$ (Direksi PTPN VIII, 2013) memakan waktu yang cukup lama yaitu 20-21 jam sekali proses. Hal ini dilakukan penghematan energi dimana mesin-mesin penggiling memerlukan modifikasi alat dan mesin atau penambahan alat dan mesin agar kapasitas alat dan mesin tersebut dapat meningkat. Jika alat dan mesin penggiling dapat ditingkatkan mencapai $1500-1700 \mathrm{~kg} / \mathrm{jam}$ maka biaya dapat dipangkas menjadi Rp. 763.121.007 setiap tahunnya. Seperti pada data pada Tabel 5.

\section{KESIMPULAN}

Adapun kesimpulan yang dapat diperoleh dari penelitian mengenai audit energi pada proses pengolahan teh hitam CTC yang dilakukan di PTP. Nusantara VIII Kebun Rancabali, Desa Rancasuni, Kecamatan Patengan, Kabupaten Bandung, yaitu: (a) penggunaan energi untuk perhitungan dengan energi tak langsung terbagi menjadi 7 tahap kegiatan pada proses pengolahan teh hitam CTC yaitu pengangkutan bahan baku pucuk teh sebesar 253,82 MJ/ton, pelayuan sebesar $514,52 \mathrm{MJ} /$ ton, penggilingan 
sebesar 709,99 MJ/ton, fermentasi sebesar 52,54 $\mathrm{MJ} /$ ton, pengeringan sebesar $1424,67 \mathrm{MJ} /$ ton, sortasi kering sebesar $859,41 \mathrm{MJ} /$ ton, dan pengepakan sebesar 115,69 MJ/ton, (b) proses pengolahan teh hitam CTC untuk satu proses pucuk teh memerlukan energi (dengan energi tak langsung) sebesar 3930,66 MJ/ton. Penggunaan energi terbesar terjadi pada proses pengeringan yang mencapai 1424,67 MJ/ton atau 36,24\%, (c) nilai hasil analisis SPACE ini berada pada kuadran I dimana kuadran tersebut mengindikasikan bahwa pabrik CTC berada posisi terbaik dimana dalam usaha penghematan energi tercapai dengan menggunakan bahan bakar alternatif yaitu 100\% wood pellet, dan (d) penghematan energi dapat dilakukan dengan memodifikasi kapasitas alat dan mesin pada proses pengolahan teh hitam mecapai $1500-1700 \mathrm{~kg} / \mathrm{jam}$ sehingga biaya dapat dipangkat menjadi Rp. 763.121.007 setiap tahunnya.

\section{DAFTAR PUSTAKA}

Abdalla, R., Herwanto, T., Saukat M., Handarto. 2017. Analisis Energi Proses Prapanen Tebu (Studi Kasus Di Pt. Rajawali II Unit Pg. Jatitujuh, Kabupaten Majalengka, Jawa Barat). Jurnal Teknotan, 11(2): 11-23

David, F. R. 2011. Strategic Management, Concept and Cases. Francis Marion University. Florence, South Carolina

Direksi PTP Nusantara VIII. 2008. Standar Operasional Prosedur Pengolahan Teh Hitam. PTPN VIII. Bandung.

Hatirli, S. A., B. Ozkan, and C. Fert. 2006. Energy inputs and crop yield relationship in greenhouse tomato production. Renewable Energy, 31: 427-438.

Herwanto, T., Nurjanah, S., Saukat, M., dan Hafidz, S. 2018. Analisis Energi Pada Proses Pengolahan Teh Hitam Ortodoks. Jurnal Teknotan 12(1): 65-72
Indarti D. 2015. Outlook teh Komoditas Pertanian Subsektor Perkebunan. Seketariat Jenderal Kementerian Pertanian Pusat Data dan Sistem Informasi Pertanian. Jakarta.

Jain, Jines C., and Takeo. 2007. A Review The Enzyme of Tea and Their Role in Tea Making. Journal of Biochemistry, 8(4): 243279

Laksmana, I. 2007. Analisis Efisiensi Penggunaan Energi Pada Industri Gula Tebu di PT. PG. Rajawali II Unit PG. Jatitujuh Majalengka, Jawa Barat. Skripsi. Fakultas Teknologi Pertanian. IPB, Bogor.

Moran, M. J and H. N. Shapiro. 2006. Fundamental of Engineering Thermodynamic, 5th Edition. John Wiley and Sons Inc. United States of America.

Setiawati, I dan Nasikun. 1991. Teh: Kajian sosialekonomi. Aditya Media. Yogyakarta.

Setyamidjaja, D. 2000. Teh Budidaya dan Pengolahan Pasca Panen. Kanisius, Yogyakarta.

Sugandi, W., Macklin, B. P., Thoriq, A., dan Rifki, F. 2021. Kajian Kebutuhan Energi Spesifik dan Kapasitas Kerja Mesin Pengering Gabah Berbahan Bakar Kayu. Jurnal Teknik Pertanian Lampung, 10(1): 16-25

Sutejo, A., Mardjan, S, S., Hermawan, W., dan Desrial. 2018. Kinerja Mesin Pemisah Potongan Tangkai dan Daun Teh. Jurnal Teknik Pertanian Lampung, 7(3): 160167.

Suprihatini, R. 2005. Daya Saing Ekspor Teh Indonesia di Pasar Teh Dunia. Jurnal Agro Ekonomi, 23(1): 1-29.

Yuliani, A dan Susanto, Eko. 2019. Pentingnya Strategi Bisnis yang Tepat Dalam Mempertahankan Eksistensi Suatu Usaha. Jurnal Manajemen Bisnis dan Kewirausahaan, 3(1): 15-22. 